The Labore Journal of Economics

Special Edition

\title{
Key Issues in Managing Pakistan's Economy Inaugural address
}

\section{Ishrat Husain*}

\section{Introduction}

Pakistan was one of the few developing countries that had achieved an average growth rate of over 5 percent over a four decade period ending in 1990. Consequently, the incidence of poverty had declined from 40 percent to 18 percent by the end of 1980 s. But the 1990 s proved to be a lost decade for Pakistan; growth in per capita income dropped to slightly over 1 percent. Poverty resurfaced and about one-third of the population now lives below the poverty line of $\$ 1$ per day. Social indicators became worse than those of other countries with comparable incomes. The country became one of the heavily indebted countries and was declared as one of the most corrupt countries in 1996. The challenge facing the government which assumed power in October 1999 was to put the economy back to its pre-1990 track.

Pakistan has come a long way since the 1998/99 crisis when the country was on the brink of default and international reserves had been depleted, economic growth was anemic, debt ratios were alarmingly high, confidence of the investor community was at its lowest ebb and credibility among international financial institutions was eroded. The economic growth rate has reached a solid 6 percent plus, inflation has been contained to 5 percent which has only recently started rising, exchange rate has been stabilized, fiscal deficit has been drastically reduced, domestic interest rates have declined dramatically, international reserves have jumped twelve times their 2000 level, debt ratios have fallen significantly and investment is booming. Pakistan's creditworthiness has been upgraded to B+ by S\&P. It is one of the few developing countries that have graduated from a successful completion of an IMF program to directly accessing international financial markets.

I will start with an overview of the economic reforms and policies put in place by the government since 2000, examining their main

* Governor, State Bank of Pakistan 
components, their aims and objectives and the degree of success achieved. I will then offer an assessment of the experience during this period and then offer some concluding remarks.

\section{Economic Management since 2000}

The turnaround witnessed in the economy has not occurred all of a sudden but is the outcome of a deliberate and carefully designed program of economic reforms undertaken over the last five years; some of them still ongoing. The comprehensive strategy announced by President Musharraf in December 1999 consisted of four key elements:

(a) Restoration of Macroeconomic Stability and Pakistan's relationship with the International Financial Institutions.

(b) Structura1 Reforms to remove distortions.

(c) Improving Economic Governance and reviving key institutions.

(d) Poverty Alleviation through targeted interventions and Social Safety Nets.

The interconnection between economic growth, poverty reduction, structural reforms and improved governance is fairly strong in the case of Pakistan. Macroeconomic stability and the consequent rapid economic growth help reduce poverty in conjunction with investment in social sectors, targeted interventions and social safety nets. Structural reforms are needed to strengthen the underpinning of macroeconomic policies and to remove microeconomic distortions affecting key sectors of the economy thus paving the way for accelerating economic growth. Improved governance affects the quality of growth by allowing realization of higher returns on investment and is also conducive to poverty reduction through better delivery of social services to the poor. Poverty reduction, as we know by now, can be achieved with rapid economic growth, structural reforms and improved governance.

\subsection{Macroeconomic Stability}

Macroeconomic stability has been achieved through reduction in the fiscal deficit, acquiring a surplus on the current account balance of payments, lowering of inflation, and a transformation of the external debt profile. These have been brought about partially through the support of international financial institutions and the Paris Club bilateral creditors 
which significantly eased the external payments position that had been a major and consistent risk to the economy since 1998.

The fiscal deficit was reduced by pursuing a combination of four sets of policy measures (i) mobilizing additional tax revenues (ii) reducing subsidies to public enterprises and corporations and (iii) bringing about a significant decline in debt servicing payments and (iv) containing defence expenditures.

Monetary policy was kept reasonably tight during the first two years with money supply growth at about 9 percent. Expansion in private sector credit in the subsequent years did not put much pressure as government borrowing was limited to a manageable level. As the monetary conditions improved, the interest rate came down gradually to a single digit and demand for credit by private businesses picked up resulting in higher capacity utilization in manufacturing and increased industrial production. However, with the mounting of inflationary pressures in recent months, the State Bank is taking measures to tighten its monetary policy; the interest rates are expected to go up gradually in the coming months so as not to hurt the growth of the economy.

External debt management focused on (a) reprofiling of the stock of official bilateral debt, (b) substituting concessional loans for nonconcessional from international financial institutions, (c) pre-paying expensive loans and (d) liquidating short-term liabilities. The debt ratio was thus reduced from 100 percent of GDP to 60 percent in five years time.

Trade policy in Pakistan has been categorized by the World Bank as one of the least restrictive in South Asia along with Sri Lanka and this policy has gradually provided incentives to exporters to increase their market share in the global markets. Exchange rate policy was pursued to maintain stability in the foreign exchange markets while at the same time keeping the competitiveness of Pakistani exports intact. A large accumulation of foreign reserves played an important role in stabilizing the exchange rate.

\subsection{Structural Reforms}

\section{Financial Sector Reforms}

The financial sector has made the farthest progress by transforming itself into a market oriented, private sector dominated sector performing efficient intermediation. Reforms that have been successfully implemented since 2000 spanned over a whole range of initiatives. Prominent among 
them were (a) privatization of nationalized commercial banks and fostering competition, (b) strengthening regulatory supervisory and enforcement capacity of the SBP (c) lowering the cost of capital by dealing with non performing loans, reducing corporate tax burden and bringing cost-income ratios down, (d) revising the legal structure particularly the foreclosure laws (e) broad basing access to the middle income and lower income groups by opening up provision of credit for agriculture, SMEs, consumer financing and micro credit (f) introducing and enforcing stringent corporate governance, internal controls, transparency and enhanced disclosure standards $(\mathrm{g})$ liberalizing the foreign exchange regime and $(\mathrm{h})$ promoting technological upgradation of the banking industry through E-banking, ATMs etc.

A financial sector assessment carried out jointly by the World Bank and the IMF concludes that Pakistan had been able to establish a sound, efficient financial system that can withstand exogenous shocks. The restructured financial system has responded well to the expansionary monetary policy that was pursued during the period 2001/02 - 2003/04 to stimulate aggregate demand and kick-start the economy.

\section{Tax Reforms}

Tax reforms have attempted to widen the tax base, strengthen tax administration, promote self-assessment, eliminate whitener schemes, reduce multiplicity of taxes and tackle the culture of tax evasion and corruption. A new Income Tax Ordinance has been introduced in 2001, which allows for universal self-assessment, uniform tax rates, removal of non-adjustable withholding taxes, elimination of exemptions and detailed audit. Moreover, the tax survey and documentation drive during 1999-2000 has allowed the CBR to bring in additional income tax payers and new sales tax payers into the tax net. It has also profiled 600,000 tax payers which will help enhance the effectiveness of tax assessment, and help detect tax evasion and underreporting.

\section{Tariff Reforms}

Pakistan made significant efforts in liberalizing its trade regime during the 1990s. The maximum tariff rate has declined from 225 percent in $1990-1$ to 25 percent; the average tariff rate stands at just 11 percent compared to 65 percent a decade ago. The number of duty slabs has also been reduced to four. Quantitative import restrictions have already been eliminated except those relating to security, health, public morals, religious and cultural concerns. The number of statutory orders that 
exempted certain industries from import duties has been phased out by June 2004 and import duties on 4,000 items were reduced. These measures have brought down the effective rate of protection, eliminated the anti-export bias and promoted competitive and efficient industries. A number of laws have also been promulgated to bring the trade regime in conformity with World Trade Organization regulations. These include antidumping and countervailing measures and strengthening of intellectual property rights.

\section{Privatization}

Public sector corporations have been a constant source of burden on the budget as well as quasi-fiscal accounts. As much as one-third of the fiscal deficit could be directly attributed to the losses of public corporations. In addition, nationalized commercial banks had been carrying a large burden of these corporations. A new law was promulgated under which privatization can take place. This step was necessary to ensure transparency, provide an institutional and legal framework, avoid unnecessary delays and litigations, and outline the process through which the transactions are to be carried out.

Four major banks along with several other key public sector units have already been sold to strategic investors in the private sector. Shares of large companies such as Oil and Gas Development Company Ltd. and Pakistan Petroleum Ltd. have been divested through public offerings. Plans to sell the Pakistan Telecommunications Co. Ltd. (PTCL) and Pakistan State Oil (PSO) - the two giants - are under implementation.

\section{Deregulation}

As Pakistan has embarked on the process of creating competitive markets and eliminating direct or implicit consumer and producer subsidies, a number of steps have been taken to deregulate prices and trading in various sectors. The most far-reaching reform has taken place in the oil and gas sector. Imports and pricing of petroleum products have been deregulated and the private sector is now free to import and fix prices. An automatic price adjustment formula for consumer prices of petroleum products linked with international prices has been adopted. Price distortions in natural gas have also been eliminated and a new pricing framework has been put in place.

The government has freed agricultural prices by moving towards market based pricing. With a view towards allowing farmers to receive 
international prices for their produce, all restrictions on the import and export of agricultural commodities have been removed. Wheat procurement and trade, which was until recently an exclusive monopoly of the state, has been opened up to the private sector. Exports of wheat and wheat products have also been allowed to the private sector.

Deregulation and liberalization of the economy have given rise to an interesting by product - weakening of the public functionaries' power to collect rents, extort bribes and exhibit arbitrary behavior. This has a positive impact on the quest for improved governance in the country.

\subsection{Governance and Institutions}

The cornerstone of the governance agenda is the devolution plan which transfers powers and responsibilities, including those related to social services from the federal and provincial governments to local levels. This plan was put into effect in 2001. The development effort at the local level is expected to be driven by priorities set by elected local representatives, as opposed to bureaucrats sitting in provincial and federal capitals. Devolution of power will thus strengthen governance by increasing decentralization, transparency, accountability of administrative operations, and people's participation in their local affairs.

Other essential ingredients for improving economic governance are the separation of policy and regulatory functions, which were earlier combined within the ministry. Regulatory agencies have been set up for economic activities such as banking, finance, aviation, telecommunications, power, oil, gas etc. The regulatory structures are now independent of the ministry and enjoy quasi judicial powers. The Chairman and Board members enjoy security of tenure and cannot be arbitrarily removed. They are not answerable to any executive authority and hold public hearings and consultations with stakeholders.

The National Accountability Bureau (NAB) has been functioning quite effectively for the last five years as the main anti-corruption agency. A large number of high government officials, politicians and businessmen have been sentenced to prison, subjected to heavy fines and disqualified from holding public office for twenty-one years on charges of corruption after conviction in the courts of law. Major loan and tax defaulters were also investigated, prosecuted and forced to repay their overdue loans and taxes. 
Transparency in public policy making, the watchdog role of a fierce and independent media and vigilance by an emerging set of civil society organizations are also beginning to make a contribution towards better governance. The Freedom of Information Act has provided the legal basis for dissipating the opacity of the decision making process.

The nascent role of the Parliamentary Sub-committees on various ministries and the strong and visible role of the Public Accounts Committee (PAC) are also acting as a brake on the whimsical and discretionary behavior of public officials. But it has to be realized that most of the accounting and financial rules are outdated and do not meet the requirements of modern management. This tension between strict observance of antiquated rules and the imperatives to take timely actions and implement policies can only be resolved if an exhaustive review of the rules is undertaken. The fear of the $\mathrm{PAC}$ and $\mathrm{NAB}$ will otherwise end in a paralysis of decision making by the bureaucracy.

\section{Institutional Reforms}

Civil service reforms aimed at improving recruitment, training, performance management, career progression, right sizing of ministries and attached departments, and improving compensation for government employees are the reforms that have been initiated to build strong institutions in the country. In order to depoliticize recruitment, promotions and career development, the independence and responsibilities of the Federal Public Service Commission (FPSC) have been enhanced and is now fully in charge of merit based recruitment and promotions. The Civil Service Act has been amended to reflect performance based career progression and would enable the government to retire civil servants who are inefficient and/or corrupt. The public sector educational training infrastructure is also being restructured to strengthen skill based training of civil servants at all levels.

The reforms in some of the most important federal institutions - the Central Board of Revenue (CBR), Securities and Exchange Commission of Pakistan (SECP), the State Bank of Pakistan (SBP) and Pakistan Railways initiated some years ago - are already beginning to take some hold and are making a difference as far as governance is concerned.

Reforms in access to justice will deal with delays in the provision of justice, case management, automation, and court formation systems. In addition, human resources, management information systems and the infrastructure supporting judicial system are being revamped and upgraded. 
Small Causes Courts have been established to provide relief to the poor who have small claims.

Extensive police reforms have been introduced to separate the law and order, investigation, and prosecution functions of the police and promote functional specialization. Public Safety Commissions have been set up at the federal, provincial and district levels, which will institutionalize public accountability of Pakistan's Police Force. To improve the overall performance of the policy, enhancing efficiency, logistics, communication, mobility and training are to be given greater emphasis. The example of motorway police in this respect is illustrative of the quick turnaround that can be brought about through better incentives and logistic support.

The progress on institutional reforms in Pakistan has not made any serious strides with a few exceptions such as the State Bank of Pakistan, Securities and Exchange Commission of Pakistan (SECP), Auditor General and more recently the Central Board of Revenue. Devolution to local government which started off very well on a good footing in 2001 has been impeded in sorting out the provincial - local government relationships.

Similarly, the reforms of Civil Service, Police and judiciary have to be intensified as part of the second generation reforms in the next five years. As these are quite tough to implement and cut across many structures and boundaries, a suitable mechanism has to be put in place to manage this process.

\subsection{Poverty Reduction}

Reducing poverty is a medium-to-long term phenomenon and it is unrealistic to expect a significant decline in the incidence of poverty in the short term. It took almost 12 years for poverty to rise from 18 percent in 1988-89 to 33 percent in 2000-01. It will take at least another decade to halve it to 16 percent, if an appropriate strategy is pursued. Therefore, it becomes essential to examine the elements of this strategy and come to a conclusion whether this objective is attainable or not.

The medium term strategy for poverty reduction enunciated in the Poverty Reduction Strategy Paper consists of four elements

(a) Accelerated Economic Growth

b) Increased Public Expenditures 


\section{c) Poverty Targeted Interventions \\ d) Social Safety Nets.}

\section{(a) Accelerated Economic Growth}

From a low of 1.8 percent GDP growth recorded in 2000-01 the growth rate picked up gradually to 5.5 percent in 2002-03, 6.4 percent in 2003/04 and most likely to reach 7.5 percent this year. Therefore the key is to sustain this high rate of economic growth over the next ten years. Investment ratios have to rise from the present level of 19 percent to 25 percent by $2009-10$ and the productivity of investment has to improve at the same time. The drivers of growth identified in the PRSP are agriculture, SMEs, construction and housing, oil and gas and information technology. While the first three will certainly accentuate the pro-poor pattern of growth and help in poverty reduction energy, security will be attained from oil and gas exploration and productivity gains from extensive use of I.T.

\section{(b) Increased Public Expenditures}

Agriculture sector growth in Pakistan is highly correlated with availability of water for irrigation. The reservoirs built in the 1960s and 1970s have made a huge difference to the food security of Pakistan. But these reservoirs are becoming silted while the requirement for water is on the rise. Thus public expenditure will give priority to water resource development through new reservoirs, rehabilitation of existing canals and barrages, lining of water courses and conservation of water. Public expenditure on education has to be doubled from 2 percent of GDP to 4 percent in the next five years and similarly health, water supply and sanitation will be given higher allocations.

\section{(c) Poverty Targeted Interventions}

Economic growth is a necessary, but not a sufficient condition for poverty reduction. Where poverty is endemic, high economic growth must be accompanied by direct poverty alleviation measures. Towards this end, poverty targeted intervention programs consisting of several major elements are being introduced. These elements include: (i) integrated small public works programs in both urban and rural areas (Khushal Pakistan Program), and the (ii) development of the microfinance sector to help improve the credit access of the poor. 


\section{Public Works}

Khushal Pakistan Program has generated economic activity in the country through local public works. The provinces, in close collaboration with the local authorities and communities, completed almost half a billion dollars of small projects creating about 1 million job opportunities along with essential infrastructure in rural and low income urban areas. The program has resulted in the construction of farm-to-market roads, rehabilitation of water supply schemes, repair of existing schools, small rural roads, streets, drains, and storm channels in villages. Moreover, the program has been supplemented with the schemes for lining of watercourses and laser land leveling, desilting canals, and provision of civil amenities in towns, municipal committees, and metropolitan corporations.

\section{Microfinance}

The role of microfinance in poverty alleviation and employment generation has been widely accepted. The government has established a micro-credit bank (Khushali Bank), as a prototype institution for providing credit access to poor households. This bank has so far reached out to 200,000 poor households throughout the country. The work of this bank has been reinforced by the Pakistan Poverty Alleviation Fund, which through a network of partner organizations in the non-governmental sector has reached out to another 300,000 poor families.

\section{Education and Health}

Pakistan's poor educational outcomes have become a major constraining influence on its quest for integration in the global economy. High rates of illiteracy, particularly among women, low educational attainment of the labor force, and lack of qualified technical and scientific manpower have impeded economic growth.

The strategic thrust of the Education Sector Reforms (ESRs) consists of (a) achieving universal primary education and adult literacy; (b) improving the quality of education; (c) renewed focus on technical and vocational education. Higher education and Science and Technological research capacities are also being bolstered in the country. Madarassahs are being brought into the mainstream educational system so that their products can find gainful employment in the economy. The National Commission on Human Development is mobilizing community volunteers to bring out-ofschool children into the system. Female educational enrolments have 
jumped in the province of Punjab since girl students were awarded monthly stipends to support their education.

The new health policy follows a "health for all" approach based on accessibility, affordability and acceptability of health services by the general population. The health strategy places greater focus on a continuous shift from curative services to preventive health services by improving the primary health care system. Improvements in health status are taking place mainly through maternal and child health, communicable and infectious disease control and elimination of nutrient deficiencies. The budget for the Expanded Program of Immunization has been increased and coverage is being expanded in rural areas as well as among women. A sound tuberculosis control program, HIV/AIDS program, and anti-malaria program are also under implementation. The shift of public expenditures from tertiary to primary and secondary health care and devolving and decentralizing financial and administrative powers to local tiers form the crux of the health sector reforms. This new approach provides a clear signal that preventive rather than curative health care will be given priority in the allocation of expenditures.

Poor access to water supply and sanitation are often associated with poor health outcomes. At present only 63 percent of the country's population has access to safe drinking water, whereas proper sanitation facilities are available to only 39 percent of the total population. The government is planning to increase water supply facilities and sanitation facilities to reach 100 percent of the population as part of the Millennium Development Goals. Construction of drinking water supply and sanitation facilities is already receiving prime importance under the Khushal Pakistan Program.

\section{(d) Social Safety Nets}

As part of the Social Safety Net Program, the government has launched direct cash-transfer programs for poor families through medical assistance and educational stipends from the Bait-ul-Maal (a public welfare program). The Food Support Program covers 1.2 million of the poorest households with monthly incomes of up to Rs.2,000 per family (US\$35). A system of needs testing has been adopted for the identification of beneficiaries by linking the program with the zakat system.

The zakat program that targets widows, orphans and the disabled has been strengthened. About two million beneficiaries received assistance from the Zakat Fund, of which 0.5 million receive assistance 
on a regular basis. It is envisaged that an additional 1.5 million will be added to the list of zakat recipients through rehabilitation schemes, which will provide micro loans of Rs. 10,000 (US\$160) to Rs.50,000 (US\$800) each for starting up small businesses. An allocation of Rs.5 billion (US\$80 million) has been made for these schemes in addition to the normal stipends to mustahqeen (the needy) out of the Zakat Fund. It is estimated that zakat contributes $10-15$ percent to the government's poverty reduction program.

The school feeding program for female students (Tawana Pakistan Program), which was successfully piloted in a few districts, will be replicated throughout the country. This program will help address malnutrition in female students as this has resulted in low enrolment, high absenteeism/ dropout rate and low cognitive achievement. It is estimated that community mobilization will strengthen the ownership of this program and lead to a 30 percent decrease in the dropout rate.

The Employees Old-Age Benefits Institution (EOBI) and provincial social security institutions provide pension and medical care benefits to private sector employees. Sindh and Punjab provide medical care benefits to about 700,000 beneficiaries and their dependents. The Workers Welfare Fund also provides support to workers and their families.

\section{Assessment and Conclusion}

\subsection{Assessment}

In making an assessment of the last five years, I will address two questions that are uppermost in the minds of most Pakistanis within or outside the country.

The first question that arises in the discussion of Pakistan's economic turnaround is as to how much of this can be attributed to the favorable external environment created as a result of $9-11$ and how much is due to better economic management.

My own assessment of the situation is that while the favorable external environment has definitely helped and reinforced the thrust of the economic policies and reforms, its impact would have been short lived and transitory in the absence of the reforms and policies and improvement in governance that have been undertaken during the last five and a half years. The macroeconomic indicators had started looking good even before Sept. 11 but the removal of sanctions, resumption of assistance, and diversion of 
remittances through banking channels definitely provided an impetus. I would argue that the reprofiling of the Paris Club Debt would have taken place in any event as the IMF had agreed on the three-year PRGF and debt reprofiling upon the successful completion of the 9-month Stand-by Program before Sept. 11. It should be kept in mind that the impact of Sept. 11 upon Pakistan's economy has not been, by any means, an unmitigated blessing. Export orders were cancelled and export target for that year was missed by $\$ 1$ billion. Shipping freights and insurance premia were raised substantially, foreign investors and buyers stopped visiting Pakistan and the fledgling I.T. industry suffered a severe set back. Some of the consequences of that shock are still lingering on in the form of a negative perception of Pakistan in the Western media.

The quantum of assistance from the U.S. accruing to Pakistan does not form a significant proportion of our foreign exchange receipts. If we combine all the bilateral official flows from the U.S. they do not, on average, exceed $\$ 1$ billion annually. Pakistan's foreign exchange earnings will amount to $\$ 25$ billion this year. Thus, contrary to the popular belief that Pakistan's economy will collapse if the U.S. withdraws its official assistance, the truth of the matter is that the amounts involved are too insignificant. What we really need from the U.S. is better market access to our exports on the same terms as allowed to the Central American, Caribbean and African States. Pakistan can earn twice as much as it will receive in official assistance from the U.S. if this market access is allowed.

The second popular view that is commonly prevalent is that we do not have independent economic policies and that we follow the policies dictated to us by the IMF and the World Bank. It is true that when we needed the IMF's assistance to reprofile our Paris Club Debt we had no choice at that time but to comply with the conditionalities set by them. But once we had achieved that objective and had set our own house in order, it was no longer necessary to agree to all their conditionalities. We did agree and implement those which were beneficial to our own interests.

Most of the policies prescribed by them e.g. fiscal discipline, mobilizing tax revenues, removing tariff barriers, privatizing public enterprises, maintaining low inflation, etc. all make perfect sense and no economist in his right mind could take an issue with them. Where the shoe pinches is that these policies are reduced to quantifiable targets and performance criteria for each quarter and for any slippages or deviations, however legitimate they may be during that particular quarter, the country is penalized and its reputation is put in jeopardy. This sort of micromanagement is resented by the economic managers of the 
developing countries- I would argue that as long as the country is moving on the right path in implementing the desirable set of reforms, the speed, phasing and sequencing should be left to the economic managers and not controlled by the IMF. As you are all aware we have said good-bye to the IMF since September 2004 and did not draw down the last two tranches to which we were entitled to on the basis of our performance. In the past, if we were confronted with the oil price shock that we are facing today, we would have certainly run to the IMF for balance of payments support and entered into a program. But, the resilience of our economy has been tested in the wake of this large oil price increase and we have been able to maintain a stable exchange rate, high reserve accumulation and low external debt ratios.

Going forward, Pakistan is faced with several major challenges. In the short term, as the inflationary pressures have become quite intense in the last 9 months, serious efforts have to be made to bring inflation under control. The poor, vulnerable and fixed income groups are the worst affected by this menace. On the demand side, monetary policy is being tightened and interest rates have been raised. On the supply side, the new wheat crop should be able to quell food inflation. There is still great uncertainty about oil prices. If they start receding from the peak levels this will have a favorable effect on the general price level and help in moderating inflationary expectations in the coming months.

The other challenge is the management of the balance of payments situation. As imports of machinery and equipment along with the higher oil bill have pushed the level of imports, the trade deficit has widened. So far, increased flow of workers' remittances, foreign direct investment and other concessional flows have been able to finance this deficit but, in the long run, widening of our export base, penetration in new markets and increasing the productivity of textile exports are the only safe ways to minimize trade imbalances.

Pakistan's Tax-GDP ratio has remained stagnant at low levels and the tax net is limited to 1.1 million tax payers of which 0.45 million are salaried workers. Thus, the dependence on regressive indirect taxes has created a disproportionately high burden on the middle and lower income groups. Tax reforms underway should aim to increase the buoyancy and elasticity of the tax system.

The biggest problem that has retarded equitable growth in Pakistan has been low investment in human development, particularly female education. More recently the active participation of the private and 
non-governmental sector has given rise to some hope that the quality of education will improve. But the critical question of access to education by the poor quintiles still has not been satisfactorily addressed. The Government has the responsibility to finance the poor households' education and health needs but it can provide these services through other providers rather than itself.

As the economy moves on the path of 7 to 8 percent sustained growth over the next decade, the shortages, congestion and inadequacy of physical infrastructure will become quite apparent. Under the given fiscal envelope the public sector development program can only finance one half of the annual requirements. The other half has to come through the private sector or private-public partnership. For the latter, we have to work out contractual arrangements whereby the end users can easily afford to pay the cost of these services.

Finally and the most important bottleneck, in my view, in the way of rapid economic growth and poverty reduction will be the lack of capacity of the Civil Service, Police and Judiciary to function as effective institutions in implementing the policies and programs, treating the citizens equitably and with respect and redressing their grievances in a just manner. The politicization of these institutions has ingrained an attitude of risk aversion and apathy, an instinct of survival and indifference towards competence and merit. Unless comprehensive reforms of these institutions are undertaken, we will have serious difficulty in maintaining the speed of growth and spreading its benefits to the poor.

\subsection{Conclusion}

Pakistan has achieved macroeconomic stability, introduced structural reforms, improved economic governance and resumed the path of high growth rates. But there is no room for complacency as we are confronted with challenges of poverty reduction, employment generation, balanced regional growth, upgrading social indicators and containing inflation.

The second generation reforms aimed at strengthening the country's institutions and their capacity to deliver basic services along with the continuation of sound and consistent economic policy and investment in human development and infrastructure will be able to steer the country on the right course. 


\section{Managing Pakistan's Economy}

\section{Charts}

\section{Real GDP growth has accelerated}

Per GDP Growth (\% yoy change)

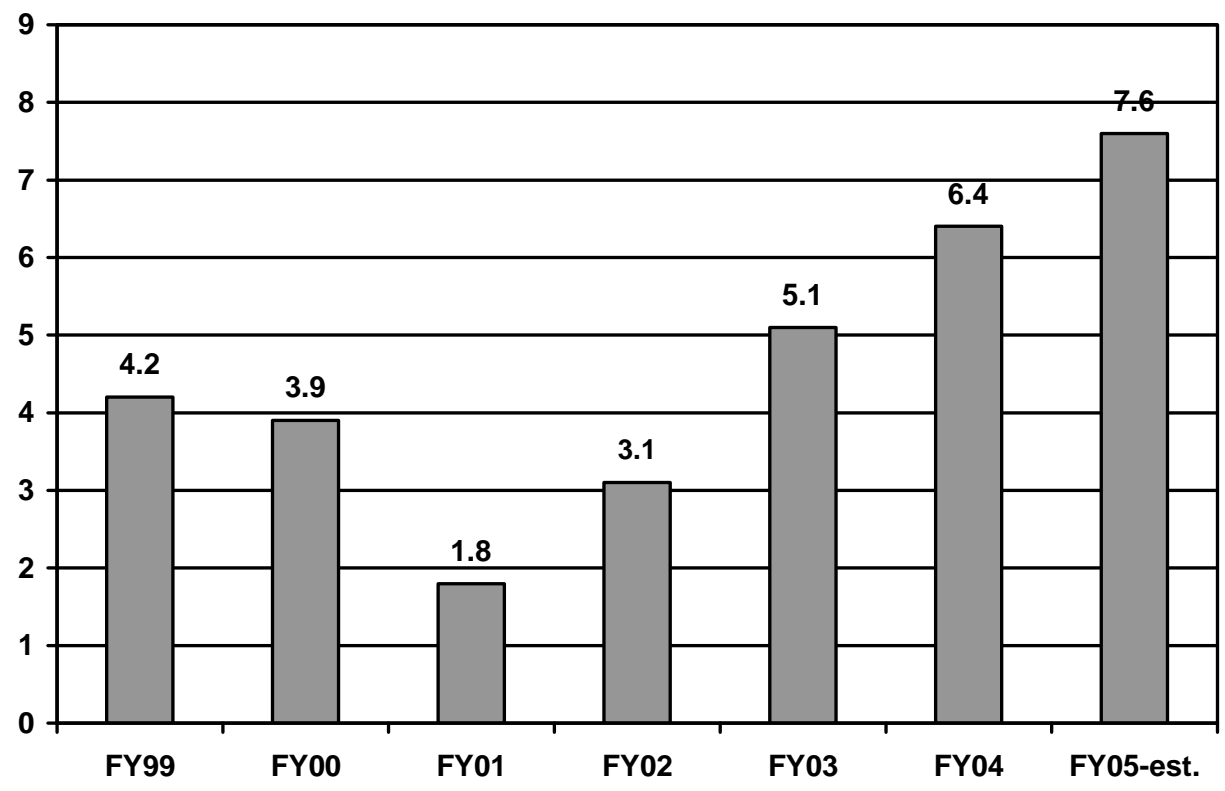




\section{Per capita income has risen}

Per capita income (\%yoy change)

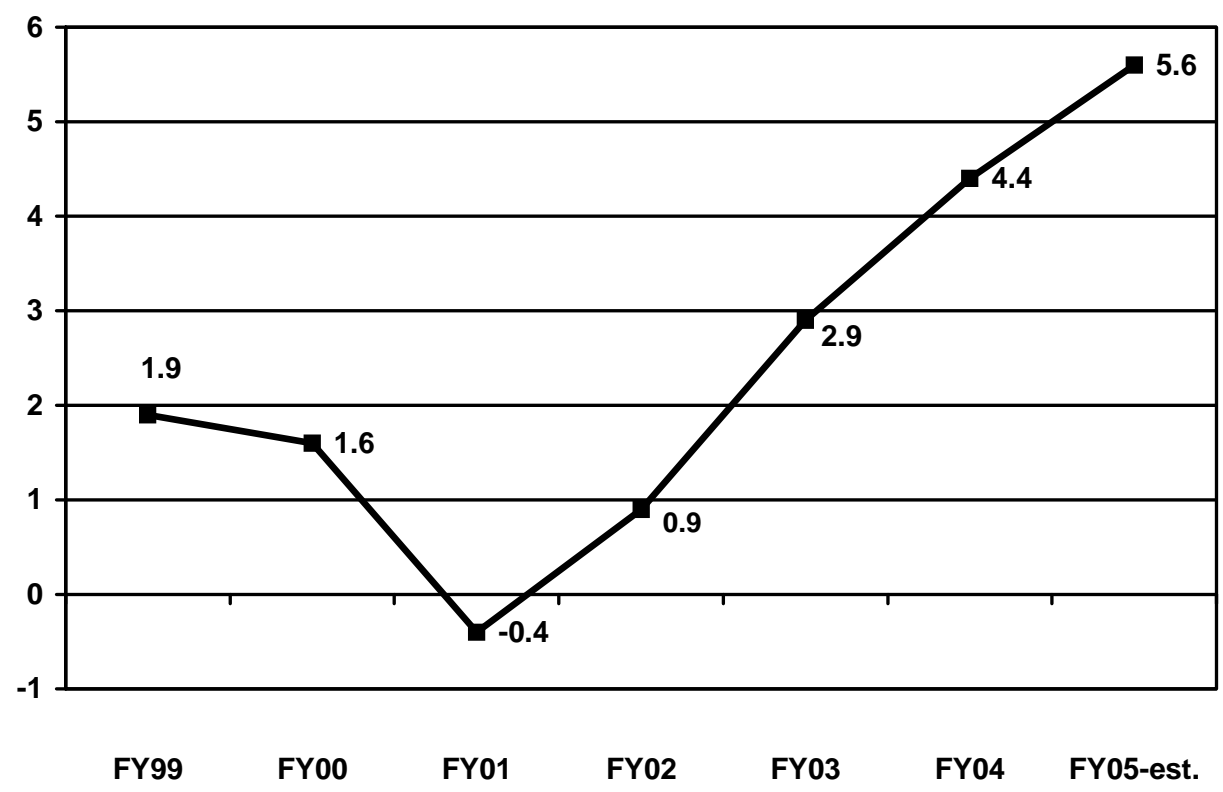

Debt services capacity has improved

Fiscal balanace (as \% as GDP)

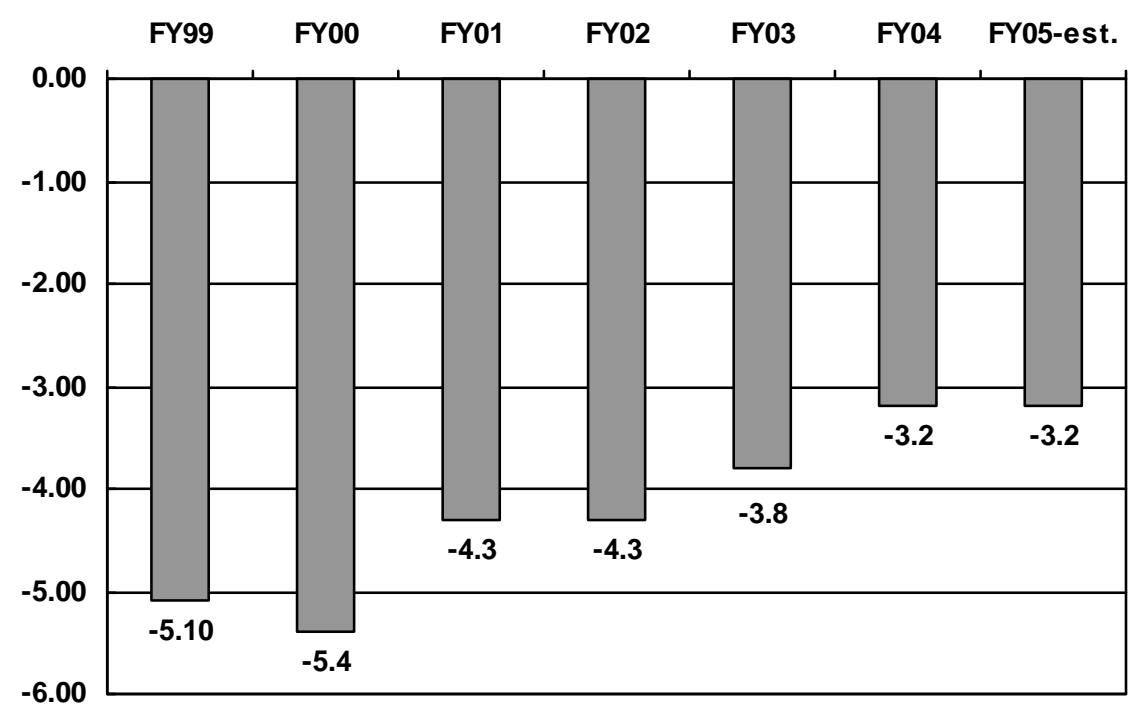




\section{Public debt has fallen significantly}

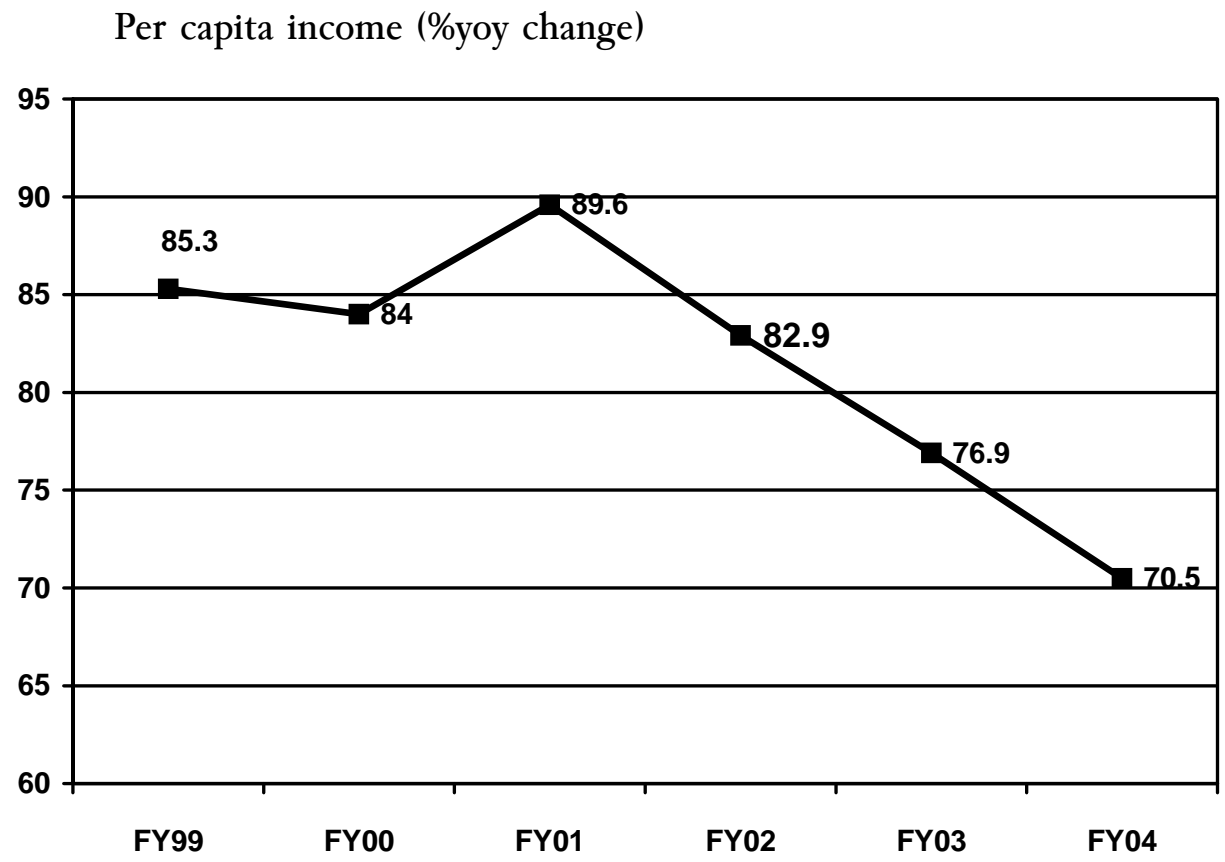

Debt serving capacity has improved

Interest Payments (as \% as Revenues)

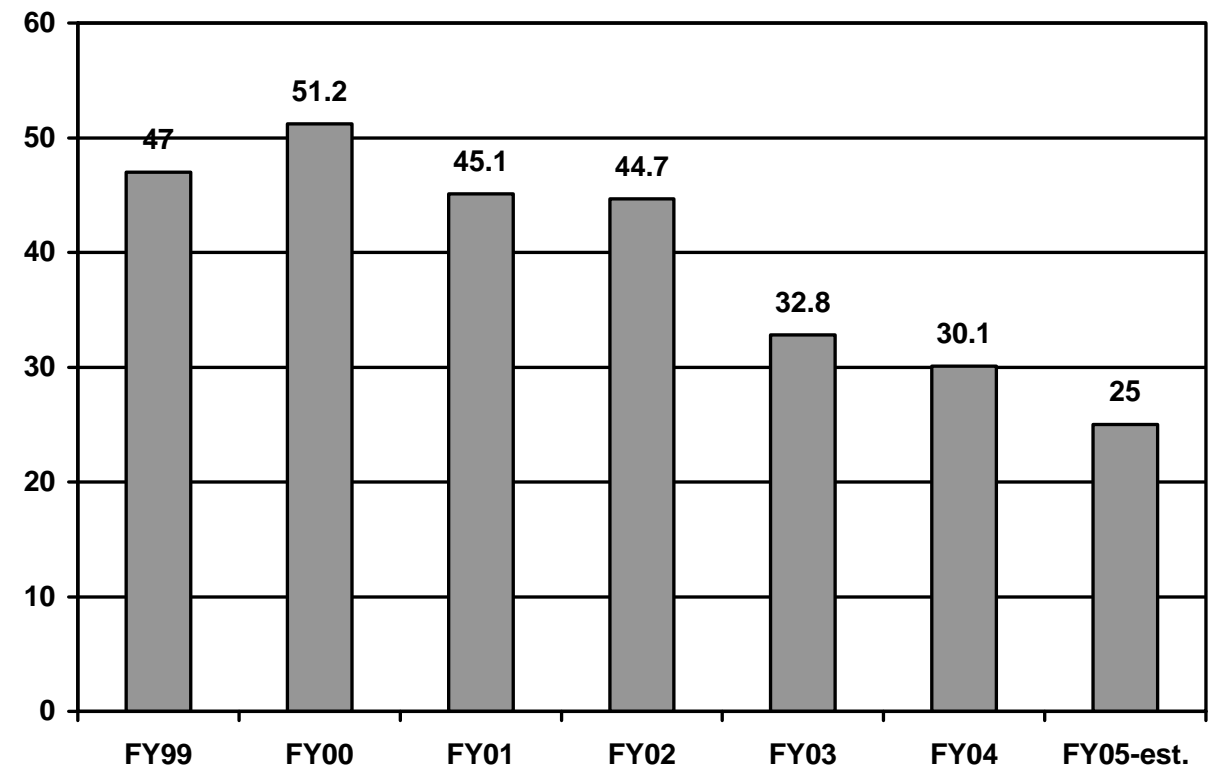




\section{External debt burden has also fallen}

External Debt (as \% as GDP)

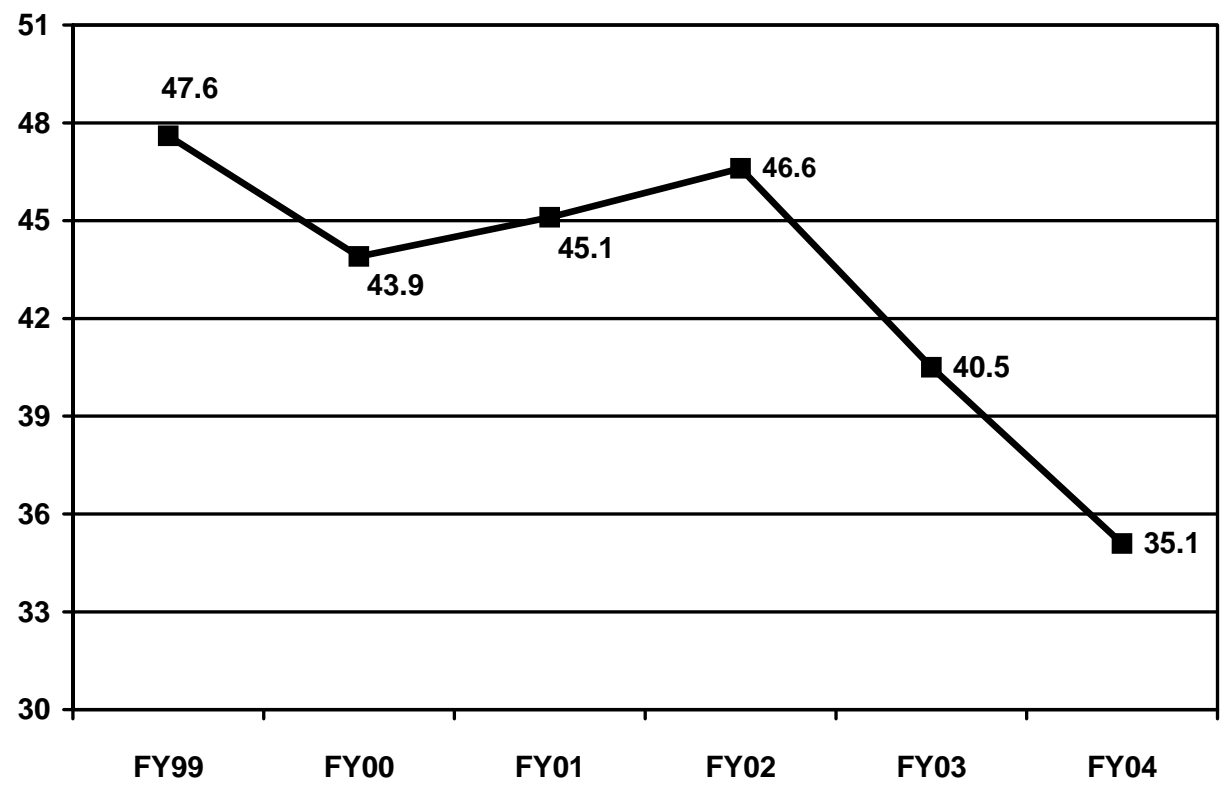

External Debt (as \% of foreign exchange earnings)

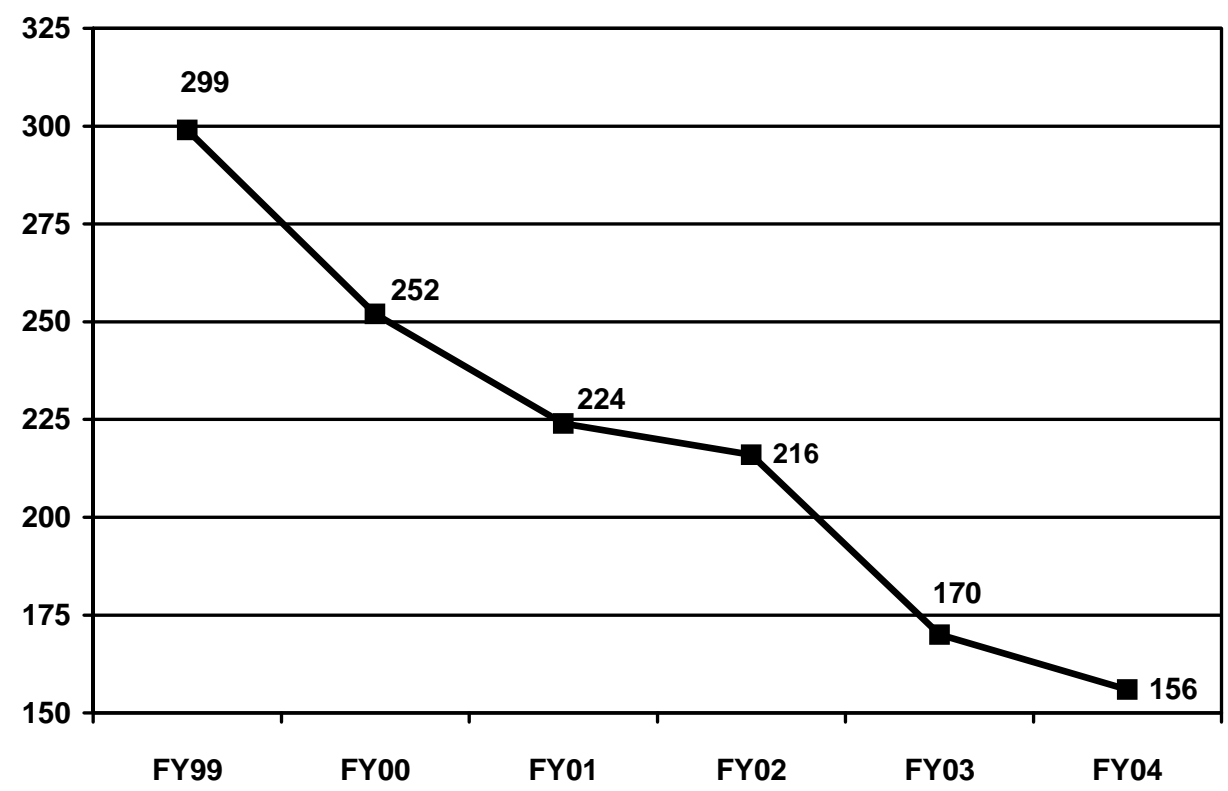




\section{Inflation remained low except this year}

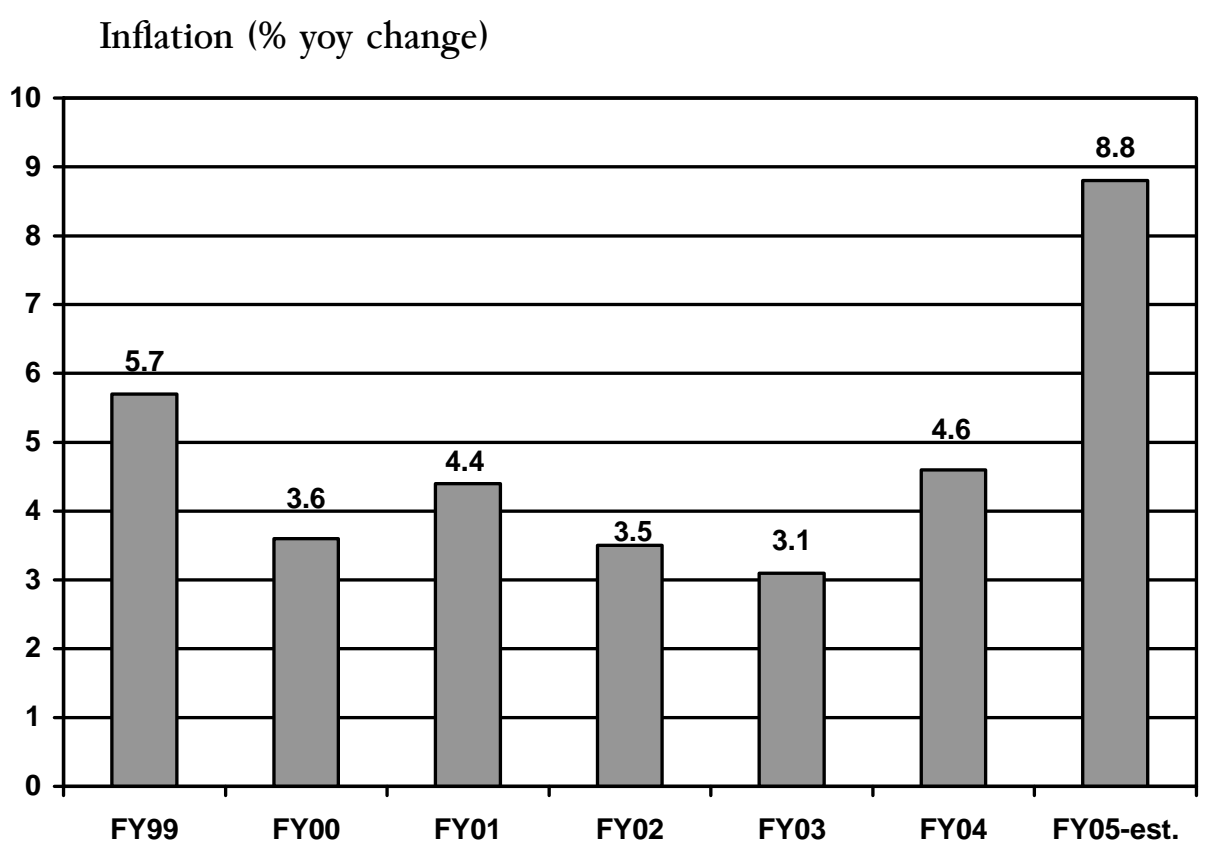

Private sector credit has shot-up

Credit to Private Sector (flows in billion Rs.)

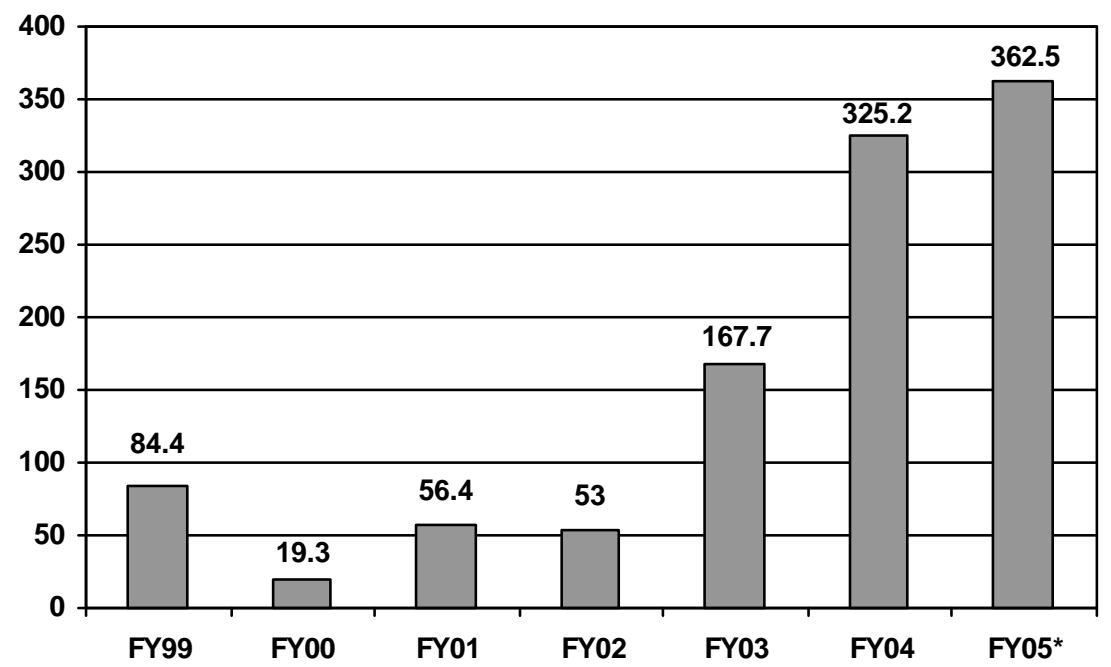

* Apr 05 


\section{Cost of capital has never been so low}

Weighted Average Lending Rates (in \%)

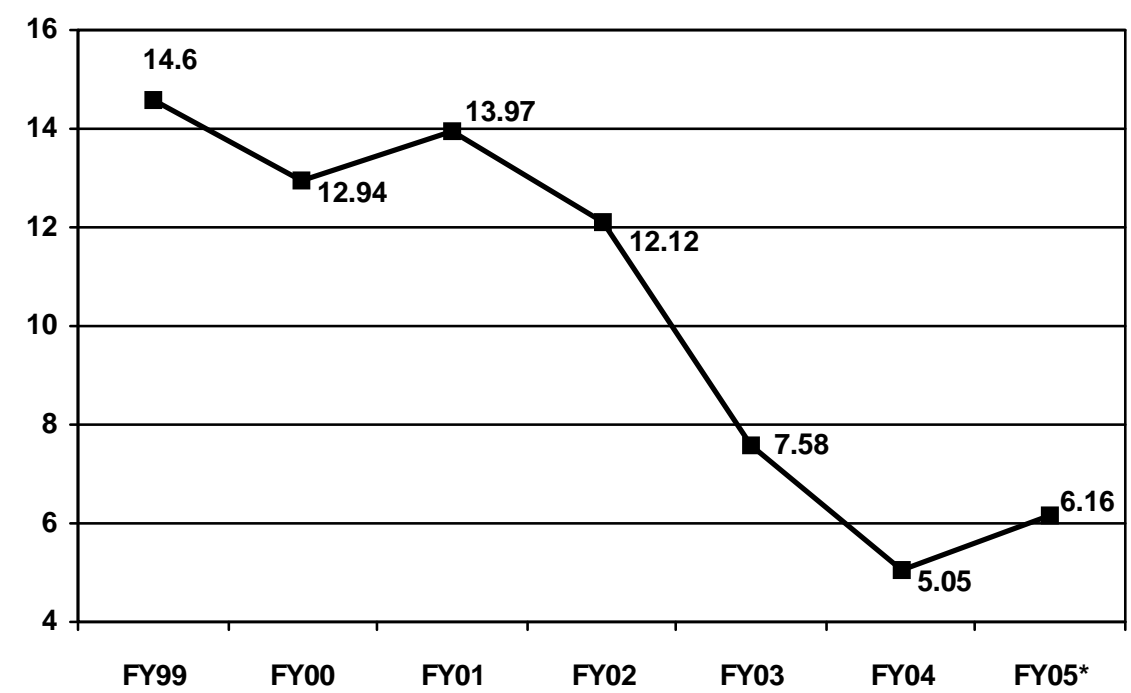

* Feb 05

\section{Import of machinery has risen}

Machinery Group Imports (billion US\$)

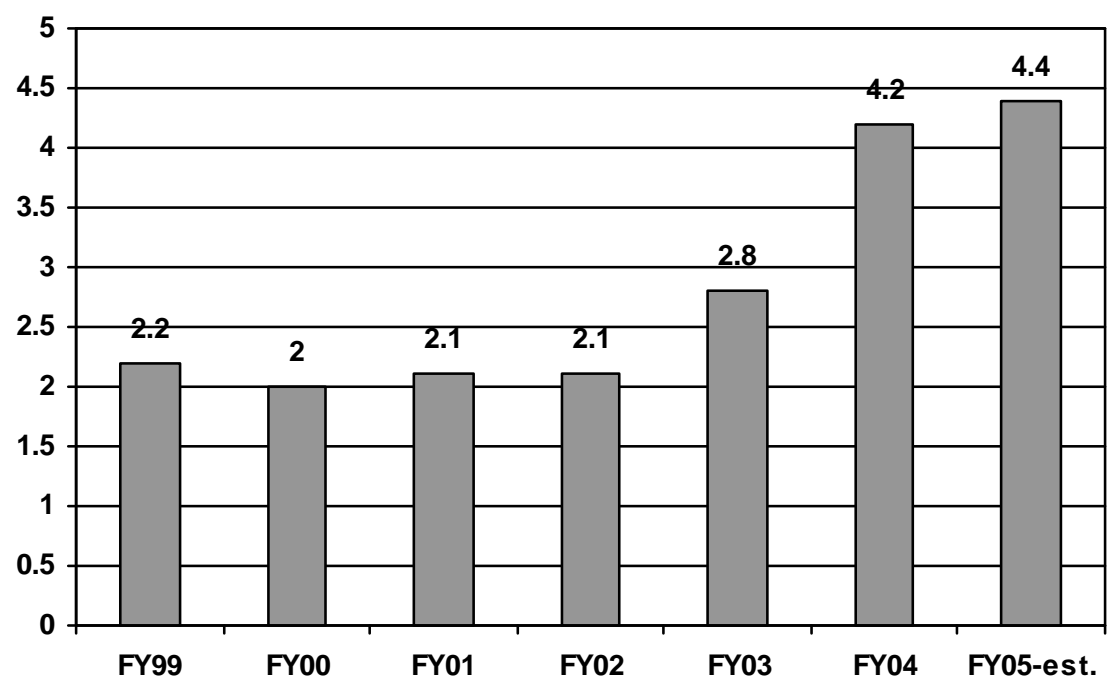




\section{Exports have expanded rapidly}

Exports (billion US\$)

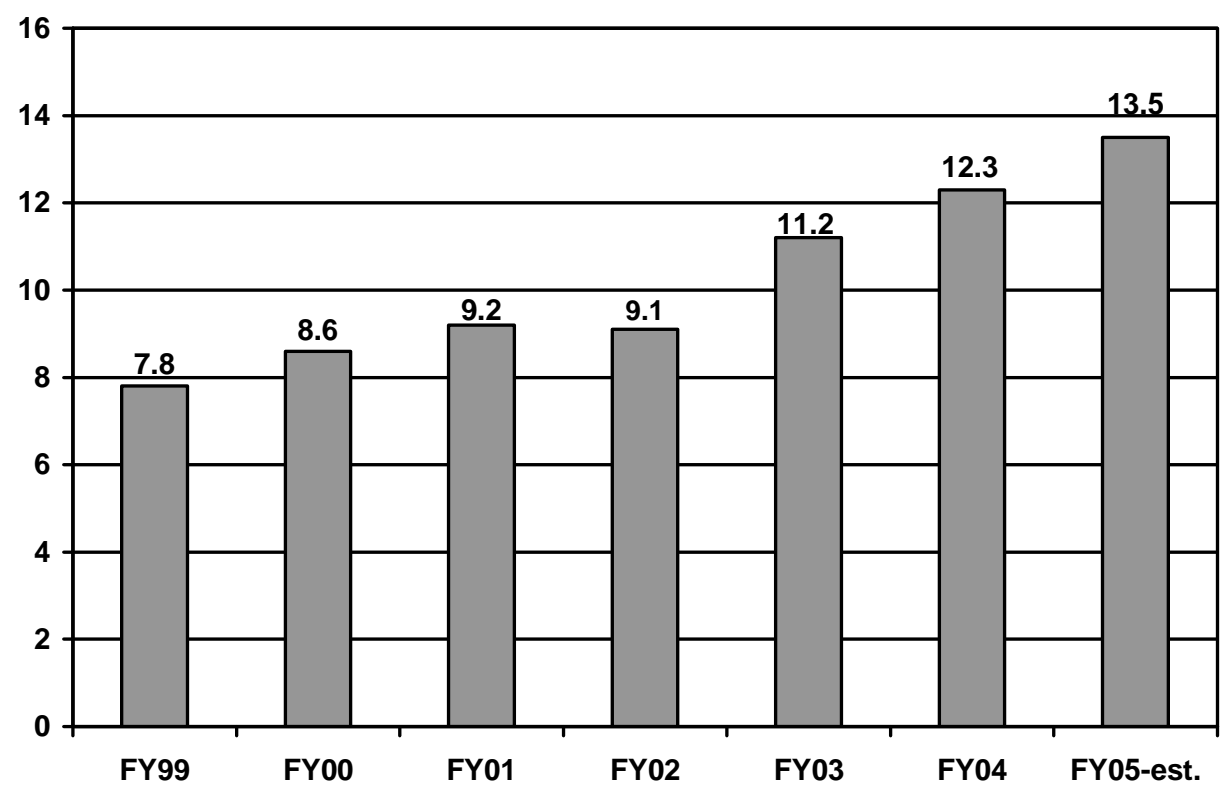

Remittances increased sharply

Workers Remittance (billion US\$)

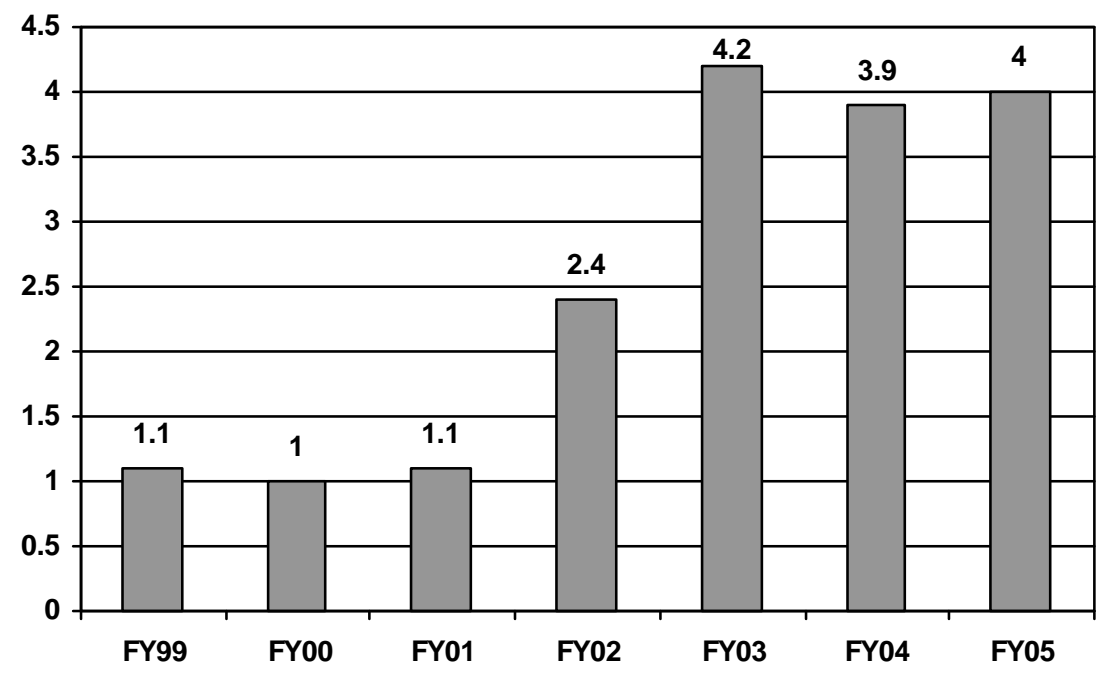




\section{Current account deficit remains under control}

Current Account Balance (as \% of GDP)

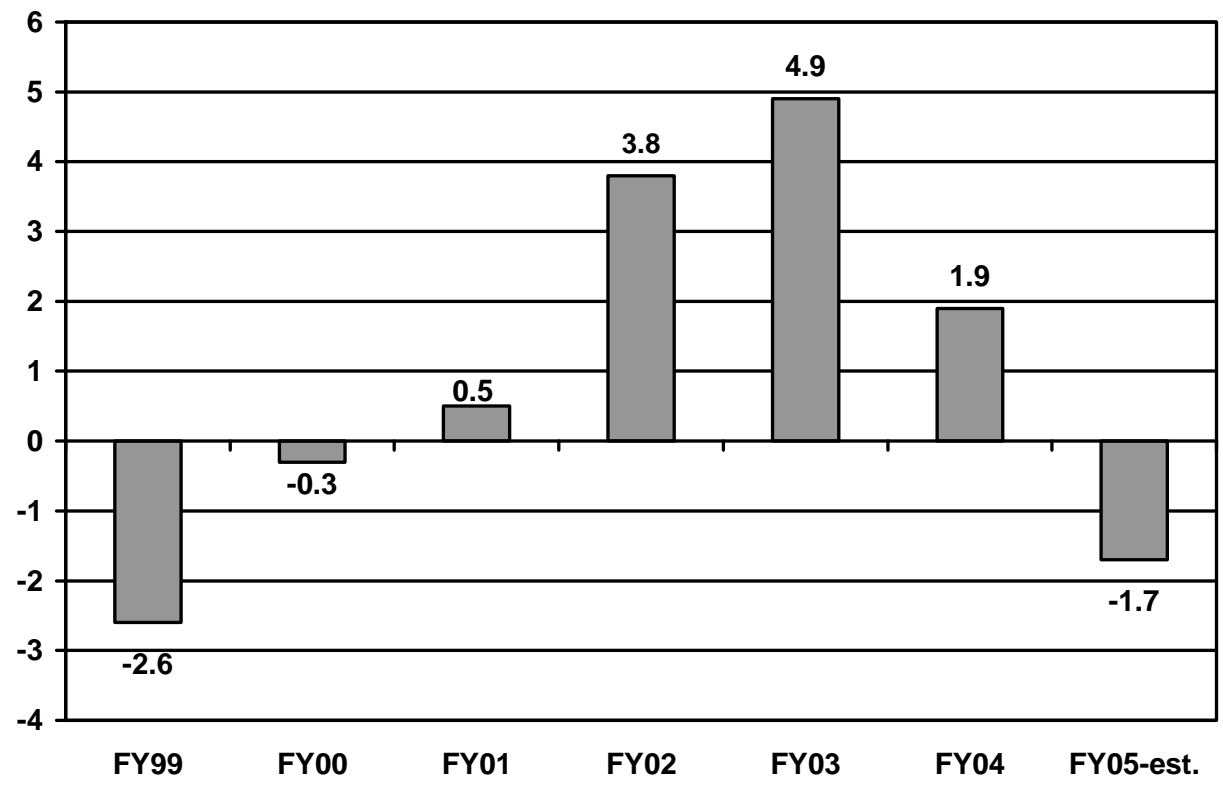

\section{External debt \& liabilities}

Tota1 External debt \& Liabilities (billion US\$)

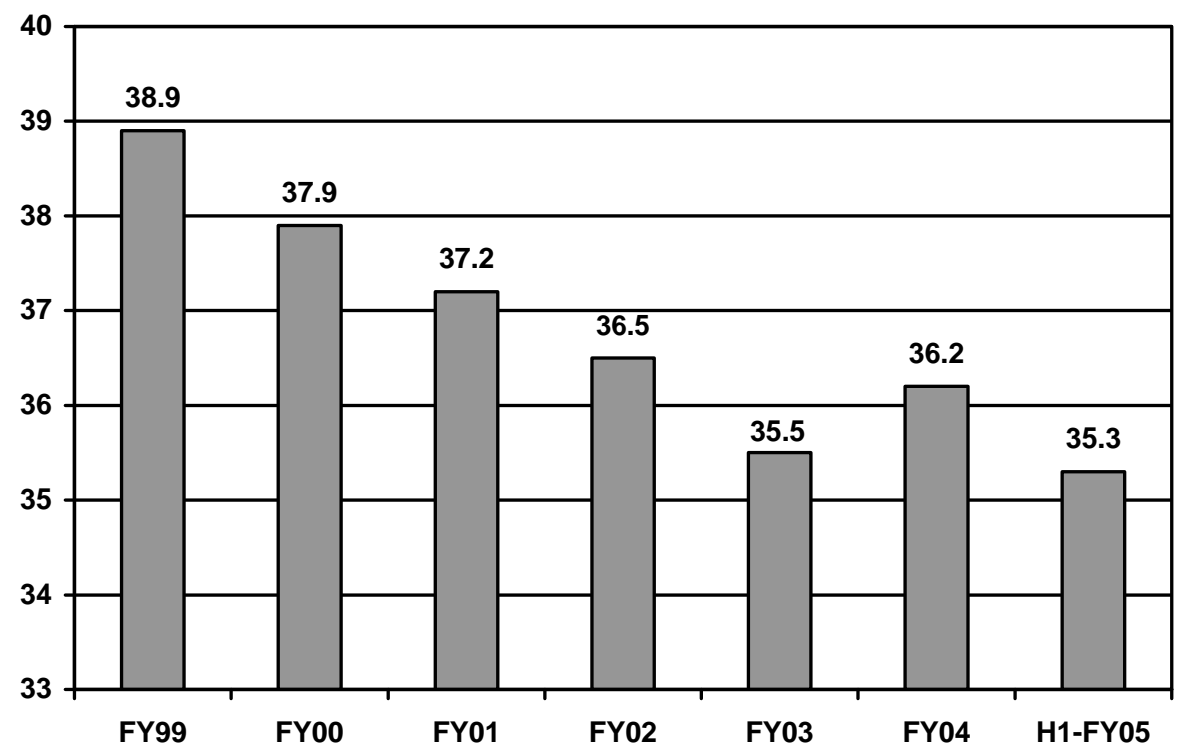




\section{Reserve position is strong}

$\square$ Liquid Fx reserves (billion US\$) — in weeks of imports (RHS)

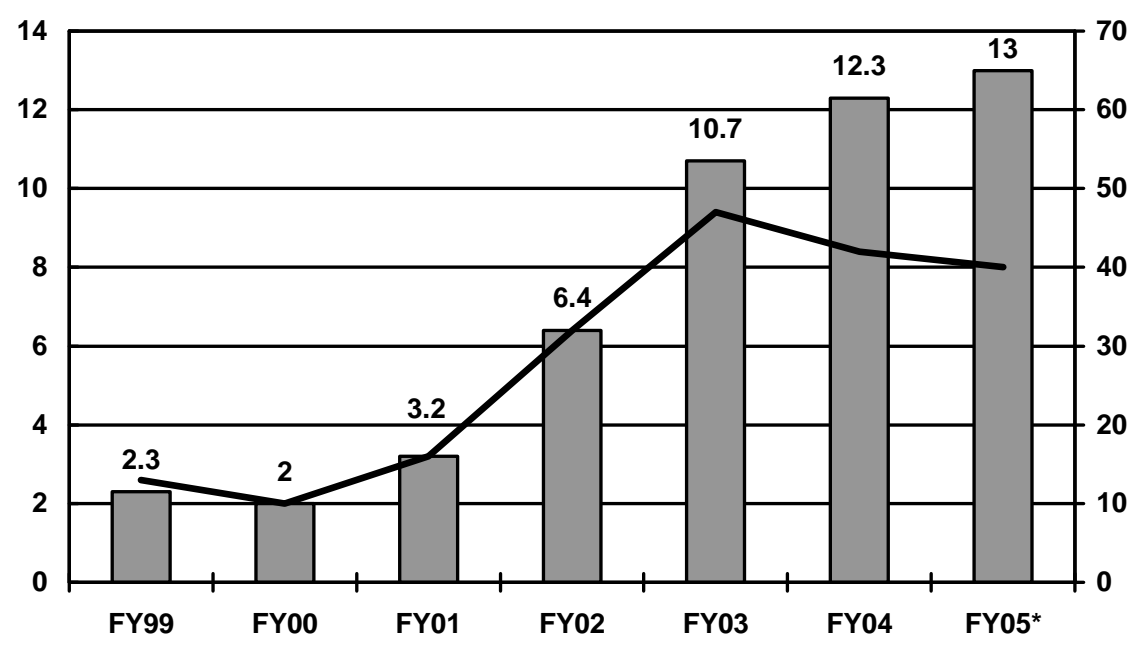

Trends in poverty

Poverty (in \%)

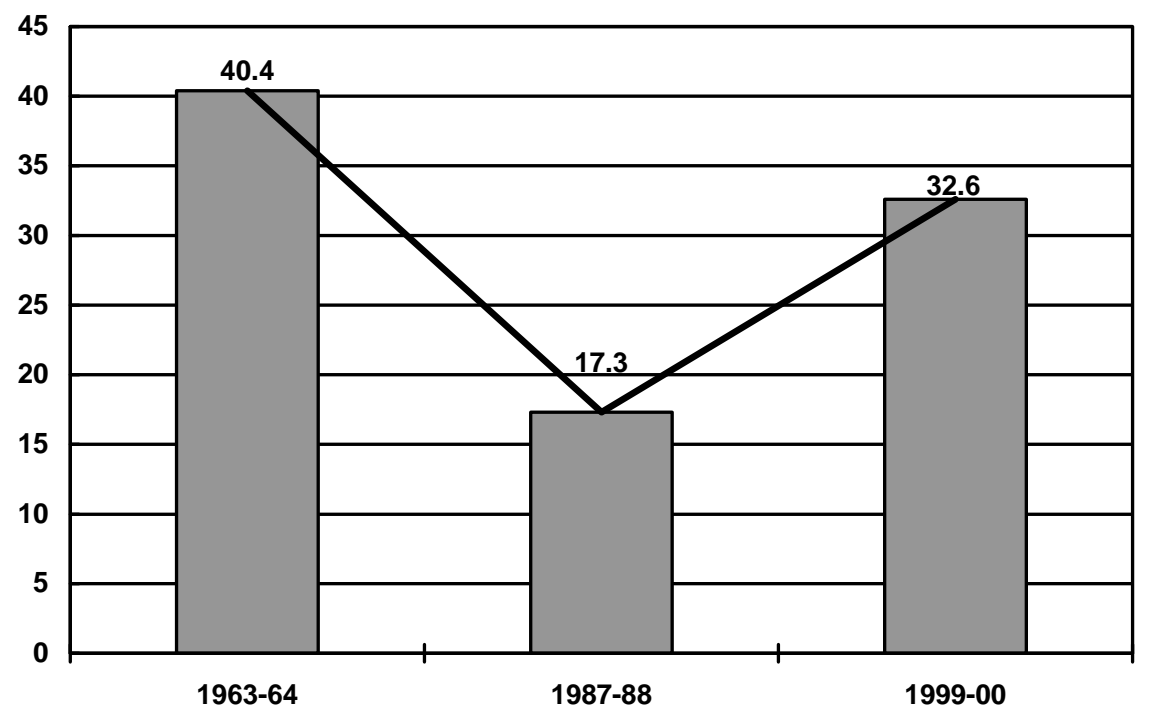




\section{Pro-poor public expenditures have increased}

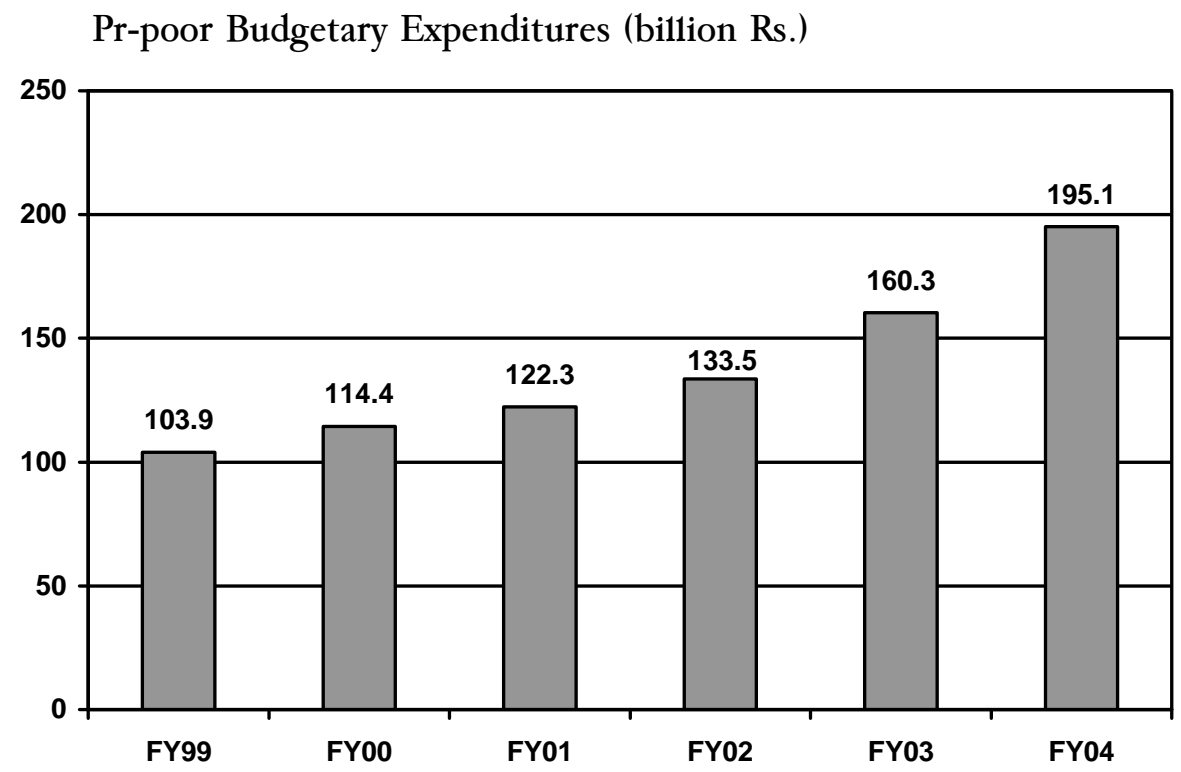

Social indicators remain weak

Selected Social Indicators - 2002

\begin{tabular}{lcccc}
\hline Country & $\begin{array}{c}\text { Life } \\
\text { expectancy }\end{array}$ & $\begin{array}{c}\text { Infant } \\
\text { mortality } \\
\text { rate }\end{array}$ & $\begin{array}{c}\text { Mortality rate } \\
\text { under five }\end{array}$ & $\begin{array}{c}\text { Pop average } \\
\text { annual(\%) } \\
\text { growth* }\end{array}$ \\
\hline Pakistan & 64 & 82 & 105 & 2.2 \\
India & 63 & 67 & 93 & 1.7 \\
Srilanka & 74 & 16 & 19 & 1.4 \\
Bangladesh & 62 & 52 & 77 & 1.7 \\
Nepal & 60 & 60 & 91 & 2.2 \\
China & 71 & 30 & 39 & 0.8 \\
Bhutan & 63 & 54 & 92 & 2.9 \\
Thailand & 69 & 24 & 28 & 0.7 \\
Phillipines & 70 & 29 & 38 & 2.2 \\
Malaysia & 73 & 8 & 8 & 2.3 \\
Indonesia & 67 & 34 & 45 & 1.3 \\
\hline
\end{tabular}

* Pop growth for 2003-04 is 1.9 percent for Pakistan Source: World Development Report 2003 


\section{Trends in unemployment}

Unemployment rate (in \%)

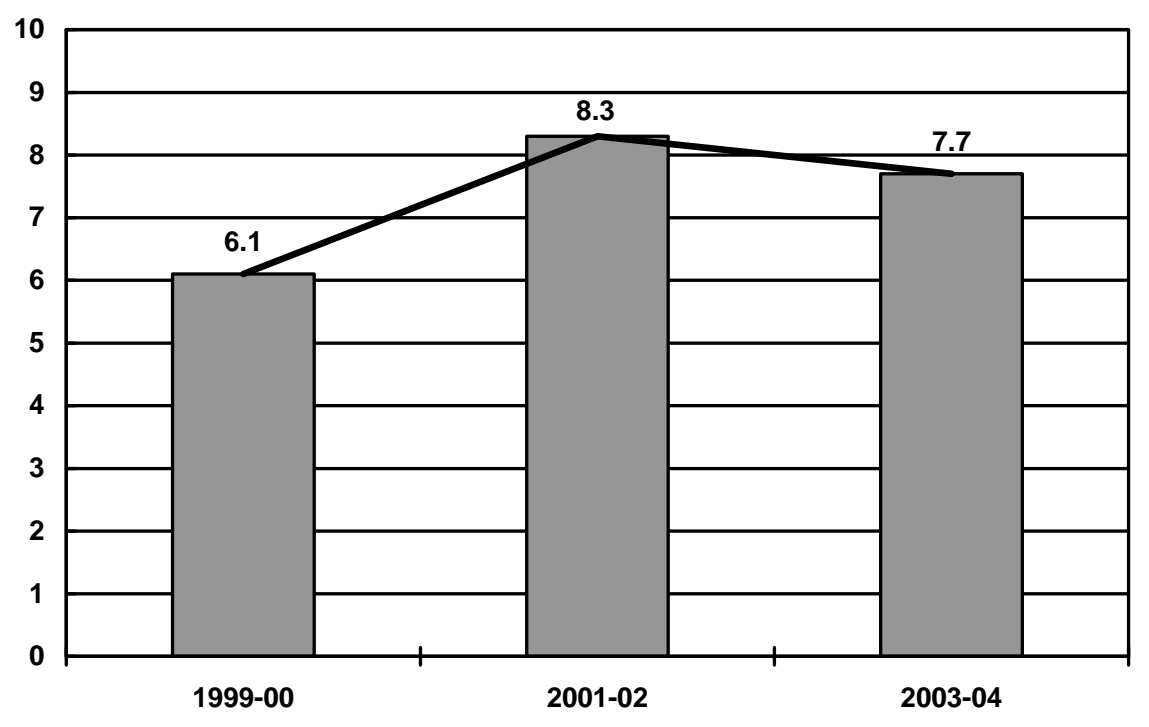

